\title{
Encomium to Hein JJ Wellens (as he chose to be known)
}

\author{
Eduardo Back Sternick ${ }^{1}$ \\ Published online: 27 June 2020 \\ (C) Springer Science+Business Media, LLC, part of Springer Nature 2020
}

2020 has brought very sad news. Apart from the COVID-19 situation, the passing of Hein now leaves us with a huge void. I first talked to Hein in 1985. Communication was not as instant as today. No internet, no e-mail. Not even fax was available. I was about to finish my training in cardiology. I had decided to deepen my knowledge on cardiac arrhythmias, choosing Maastricht as the place, and Hein as the role model. I wrote a letter to Franz Wackers, a Dutch cardiologist working in the USA, who knew Hein well, having trained with him in while Hein had still been in Amsterdam. He was short in his answer. "Send the man a letter - he is a very straightforward person!" One year later, I met Hein in Maastricht, and he accepted me as a research fellow. The time I spent in Maastricht had a profound impact on me. I was able to perfect clinical, teaching, and research tools that would serve me forever. A number of Latin American doctors had also made the same sage decision to go to Maastricht, such as Luz-Maria Rodriguez and Pedro Iturralde from Mexico, Diego Vanegas from Bogota, Rodulfo Oyarzun from Santiago de Chile, Enrique Retyk from Buenos Aires, and Mauricio Duque from Medellin. All subsequently established a solid career in clinical electrophysiology. Other Brazilian cardiologists, notably Fernando Cruz, Jacob Atié, Tamer Seixas, and Ayrton Klier Perez, followed my steps. They were also trained by Hein, not at the old and beautiful medieval St. Annadal Hospital, which had been my "home," but at the brand new University Hospital.

I became really close to Hein from 2002 onwards, when I decided to submit a doctoral thesis to the University of Maastricht, with him as my sponsor. I remember a moment of great joy for me, back in 2003, when he and Inez kindly invited me to dinner. I decided to show him the preliminary results of my investigations of Mahaim connections. When I showed him that most patients had a small but consistent electrocardiographic abnormality, not previously reported, he went to his office and retrieved the tracings from a young patient he had included in his

Eduardo Back Sternick

eduardosternick@gmail.com

1 Arrhythmia Unit, Biocor Instituto, Alameda do Morro 85, Olympus, T-4, Suite 1900, Nova Lima, Minas Gerais 34083-006, Brazil seminal doctoral thesis published in 1971. The $r S$ pattern I had recognized [1] was present, and he was happier than me! It was a unique situation, where an ex-Fellow returned to the University 16 years after finishing his fellowship. Hein acknowledged this in his speech at the ceremony. The reason was that I wanted to start a database with my own patients. As I wrote in my thesis, the internet by then allowed this to happen. We subsequently became good friends, and never stopped doing collaborative work together.

Throughout his career, he has been a true giant. He remained intellectually active and productive until the very last. It is in that regard that I now feel his loss to be even greater, since it has been a huge privilege and pleasure for me to interact with him for so many years. He was always available, and eager to contribute on any scientific issue. His comments were always apposite and significant. In addition to his great intellectual gifts, he was a true Gentleman in the English sense of the word. Over the last few days of his life, facing a terrible disease, with palliative care, and the eminent prospect of death, he found the strength and the will to send dozens of mails to friends and colleagues, with a positive message and continuing friendship.

We will all miss him greatly, as will the world of electrophysiology.

\section{Compliance with ethical standards}

Conflict of interest The author declares that he has no conflict of interest.

\section{Reference}

1. Sternick EB, Timmermans C, Sosa E, Cruz FES, Rodriguez LM, Fagundes MA, et al. The electrocardiogram during sinus rhythm and tachycardia in patients with Mahaim fibers: the importance of an 'rS' pattern in lead III. J Am Coll Cardiol. 2004;44:1626-35. https://doi.org/10.1016/j.jacc.2004.07.035.

Publisher's note Springer Nature remains neutral with regard to jurisdictional claims in published maps and institutional affiliations. 